International Journal of English Literature and Social Sciences
Vol-6, Issue-1; Jan-Feb, 2021

\title{
Purposeful Distraction: Analyzing the significance of Dust 'staub' and Distraction 'zerstreuung' in The Alchemist and Brida
}

\author{
Samragngi Roy
}

Department of English, Jadavpur University, Kolkata, India

Received: 11 Nov 2020; Received in revised form: 23 Jan 2021; Accepted: 12 Feb 2021; Available online: 26 Feb 2021

(C)2021 The Author(s). Published by Infogain Publication. This is an open access article under the CC BY license

(https://creativecommons.org/licenses/by/4.0/).

\begin{abstract}
The subject of distraction has been explored by several writers and philosophers alike. However, most of them have taken the etymological meaning of the word, 'to pull apart or separate' too literally and addressed the subject primarily based on the negative connotations attached to it. Paulo Coelho, however, gives the concept of distraction a unique twist in his two bestselling novels- The Alchemist (1988) and Brida (1990). This paper is going to explore the creative, ludic, emancipatory potential of dust and distraction that he champions in his two most celebrated works and how that enables him to contribute to the legacy of removing the stigma off the word 'distraction' and infusing it with a new, positive meaning.
\end{abstract}

Keywords - paulo coelho, the alchemist, brida, philosophical fiction, dust, distraction, emancipation.

\section{INTRODUCTION}

The word 'distraction' carries a baggage of negative connotations. More often than not, it is associated with madness, insanity, hindrance, frenzy, interruption, disturbance, hysteria, delirium, perplexity and other similar words. Distraction is often caused by the inability to pay attention, lack of interest in the object of attention, or a great intensity, novelty or attractiveness of something other than the object of attention. A distracted studen is always at the receiving end of the teacher's wrath, a distracted lover is assumed to have a wandering eye, a distracted driver causes endless road accidents and a distracted workman costs more than he ever contributes.

According to the Oxford Learner's Dictionaries, the meaning of 'distraction' as a noun is "a thing that takes your attention away from what you are doing or thinking about" or "an activity that entertains you". Here 'distraction' has been presented as a hindrance and as a source of diversion respectively. However, notwithstanding the diverse implications of the same word, the core meaning remains the same. Distraction, by default, means a lack of attention or interest in one's primary responsibilities or the task at hand. When we say someone is distracted, what we essentially mean is that the person is not fully present in the moment.

Distraction is used as a source of comedy in most works of fiction. The amusement stems from either the laughter evoking gullibility of the distracted character or the peculiarity and absurdity of whatever is utilized to create that distraction ("Distraction") like La Bruyere's famous character, Menalque, from Le Distrait. Spiritual distraction is when one's thoughts are turned away from the requirements of an organized religion. That individual is thus believed to stray farther and farther away from the path of God or one's own individual faith (Mahoney, 2019). In magic and warfare, distraction is popularly used as key strategies to con the opponent army or the audience as per the convenience of the soldiers and magicians, just like con artists, shoplifters and armed robbers make use of crafty diversions to facilitate their crimes.

In the past too various authors and philosophers have spoken about 'distraction' in various different ways. According to Aristotle, distraction is the equivalent of "not-always-thinking" (North, 2012), and if we place it 
right next to Descartes' (1637) famous saying "I think therefore I am," the very existence of a distracted individual seems to be invalidated. La Bruyere believes that a distracted person neither dwells in the past nor in the present, and that he is at the same time an individual and a collective because distraction is "an aggregate of unthinking acts" (North, 2012) and Franz Kafka (1948) had once famously written in The Blue Octavo Notebooks "evil is whatever distracts." Hence, we cannot talk about 'distraction' without taking into account the various negative ways the word has been defined by authors and philosophers alike.

Paulo Coelho, however, in his famous works The Alchemist (1988) and Brida (1990), offers a refreshing change in the way the theme of distraction has been presented in Literature. Unlike the conventional implications of the word which more often than not has something to do with inattention, insanity, deceit or trickery, Coelho has viewed it from a unique perspective by suggesting that distractions are what ultimately lead one towards fulfilling one's destiny. The core message of his path-breaking philosophical fiction The Alchemist seems to be that one should embrace distractions as milestones that will lead one towards achieving one's true goals. This idea might seem outrageous and even ludicrous at the outset because we are so used to equating distraction with absentmindedness, disruptions and by extension failure, but in this particular novel, distractions come in the form of 'omens' and 'opportunities' that form a part and parcel of the Universe's greater plan for an individual. If one follows the breadcrumb trail of these 'omens' that present themselves from time to time, even if it leads that person astray from the path that one had originally set one's heart on, it ultimately results in the fulfilment of greater things. The conventional belief is very different from what seems to be the philosophy in The Alchemist. We have been brought up on the principle that pure, unadulterated focus is the only virtue that can enable one to achieve one's goals and that is what is being contested here.

\section{THE ALCHEMIST}

\subsection{Distraction in The Alchemist}

Santiago, the protagonist of Paulo Coelho's The Alchemist, is very clear about what he wants from his life- to travel the world and to marry the Andalusian merchant's ravenhaired daughter. He was destined to be a priest. Santiago, however, had no interest in priesthood. Hordes of people passed by his village from time to time and all he ever dreamed of was to visit their homes and see how they lived. His father often told him that these tourists could afford a trip to their village because they were extremely rich and that, "Amongst us, the only ones who travel are the shepherds" (Coelho, p. 9). Santiago thus set his heart on becoming a shepherd. His turning away from his religious occupation and embracing a life of adventure and romance is itself an example of spiritual distraction.

His love for the merchant's daughter, distracts him further from his greater dream of travelling the world because marrying that girl would require of him to settle down, establish roots and give up the life of adventure that he so cherished. These two desires were conflicting in their respective natures and Santiago knew that very well. Distracted from the one true purpose of his life by the temptations of love and lust for the merchant's daughter, he often finds his mind agitated. He is confused about which life to choose. His travels are interrupted frequently by thoughts of the girl and the unnerving anxiety that perhaps other wealthier, more learned shepherds had already reached her before he could and had asked her father for her hand.

Santiago's distraction begins full-fledged when he has a recurring dream. While anyone would have dismissed the dream easily as a figment of one's own imagination, a volatile mind like that of Santiago couldn't just let it go. He decided to consult a gypsy at Tarifa who was known for her ability to interpret dreams and other forms of divination like clairvoyance and palm reading. It is here that the gypsy interprets his dreams and tells him that a treasure awaited him at the Egyptian pyramids and finding that treasure was his life's true destiny- "In order to find the treasure, you will have to follow the omens. God has prepared a path for everyone to follow. You just have to read the omens that he left for you" (p. 28) Even though Santiago's immediate instinct was to dismiss whatever the gypsy had predicted, 'distraction' kept presenting itself to him in various forms and figures trying to redirect him towards the treasure that the Egyptian pyramids held in store for him.

This becomes clear through the conversation between Santiago and the king of Salem, Melchizedek. Pointing to a baker standing in his shop window, Melchizedek said, "When he was a child, that man wanted to travel, too. But he decided first to buy his bakery and put some money aside. When he's an old man, he's going to spend a month in Africa. He never realized that people are capable at any time in their lives, of doing what they dream of" (p. 21) What he essentially meant was that in the hunt for stability, people often give up on their dreams. They are afraid to risk what they have because they would rather play safe. Some people are so attached to the idea of stability and playing safe that they do not look back at their dreams anymore, that even fantasizing the fulfilment 
of those dreams is viewed as a sort of 'negative distraction', or when they finally do, it's too late.

"Why are you telling me all this?" (p. 22) Santiago asks Melchizedek after he's deliberated on it for a while. "Because you are trying to realize your destiny. And you are at a point where you're about to give it all up," (p. 22) he replies. "And that's when you always appear on the scene?" (p. 22) Santiago further asks. "Not always in this way, but I appear in one form or another. Sometimes I appear in the form of a solution, or a good idea. At other times, at a crucial moment, I make it easier for things to happen. There are other things I do, too, but most of the time people don't realize I've done them" (p. 22) is the king of Salem's reply.

This is the idea around which the entire novel revolves. At various points in the novel, the boy comes across different things and different people who distract him from his premeditated path and help him advance towards his destiny or 'Maktub' (p. 56) by either helping or hindering his immediate objectives. One might be tempted to call these hindrances 'distractions' but in the larger scheme of things, one thing leads to another and in the end all the various pieces fall beautifully on the puzzle exactly where they are supposed to fit. In the search for his own quest, Santiago himself becomes a source of 'distraction' in other people's lives, thus leading them unknowingly towards their own destinies.

For example, 'distraction' once presents itself to Santiago as a tour guide. Now this tour guide is actually a thief. So, a double disguise is at play here and we can associate this distraction with the kind of crafty diversions, deceit and trickery that magicians, thieves and con artists use to outwit people. The moment Santiago has trusted him with all the money he owned, he lets him wander distracted at a crowded marketplace looking at beautiful swords, avails of the opportunity and escapes with all his life's savings. At the outset it might seem that a moment of slight distraction has spelled doom for Santiago, in accordance with the traditional way of thought which equates distraction with loss and failure. However, this is the event that compels Santiago to find a job at a crystal merchant's store. The merchant's business had been stagnant for thirty years. But Santiago's presence in the store and his bold ideas for the business radically transform both their fates.

At the beginning, Santiago is extremely discouraged after being robbed. All he wants to do is to earn enough money at the crystal store, abandon his destiny of finding the treasure, go back home, buy a flock of sheep and thus slip back into the life of stability and security. So, he works there for a year with those aims in mind. However, while working for the merchant, he also challenges the merchant's attachment to stability by daring him to expand his business and explore new horizons, and it is because the merchant embraces his ambitious ideas, takes the much-needed break from the sameness that he had grown so comfortable with and opens up his heart to a challenge that at the end of one year, his business has flourished like never before. Santiago too has earned a sufficient amount of money, he's all set to go back to Spain but he is suddenly distracted by the two stones that had been offered to him by Melchizedek, Urim and Thummim, which fall out of his pouch just before he is about to depart and his thoughts immediately travel back to the old king of Salem and his words, "I'm always nearby, when someone wants to realize their destiny" (p. 62). He thinks about the old king for a very long time playing with the stones in his hand and then finally changes his mind. He now wants to go to the pyramids, thus giving in to 'distraction' once again.

\subsection{Dust in The Alchemist}

There are several references to 'dust' in the text. Santiago's desire not to settle down anywhere further classifies him as a somewhat diasporic individual. This is where the idea of 'staub' or dust gets associated with 'zerstreuung' or distraction. Just like dust can disperse easily, blown away by the wind, so can Santiago. Just as dust can disperse easily, so can the thoughts of a distracted individual and here is where Santiago becomes the embodiment of 'zerstreuung'. He longs to be like the dust so that he can disperse, for 'dispersion' forms the 'streuung' in 'zeustreuung'. He wants to be "able to reach every corner of the world, cross the seas, blow away the sands that cover my treasure, and carry the voice of the woman I love" (p. 140). Santiago thus becomes the symbol of the complex trinity of 'staub' (dust), 'streuung' (dispersion) as well as 'zerstreuung' (distraction) all in one.

A reference to dirt further comes up when Santiago first spots the crystal merchant's store. He offers to clean up the glasses in his shop and in return he asks the merchant to give him something to eat. The crystal glasses in his shop were 'dirty'. They had collected dust from sitting in the same place for years and Santiago believed that no one would be willing to buy the glasses if they looked so dirty. While Santiago cleaned the glasses, a couple of customers entered the store and made their purchases. This hadn't happened for a very long time and the crystal merchant could immediately perceive that Santiago was a good omen. The dust on the glasses which had until now distracted potential customers away from the crystal merchant's store was finally being engaged with and that brought in new customers. Dust and distraction are so 
inextricably linked here that as long as the glasses were under thick layers of dust, they could attract no attention or interest of the potential customers but once the dust was engaged with, the distraction was dispelled too. Or alternatively, we can also say that the removal of the dust distracted the potential customers away from whatever their minds were engaged in and attracted them towards the crystal glasses. So, dust and distraction not only coexist but also complement each other and at times it even becomes difficult to distinguish between the two.

On his way to the Egyptian pyramids through the vast desert made of literal 'staub', he finds the alchemist who knew how to turn any metal into gold. The arrival of the alchemist, a further distraction that Santiago encounters on his way, is also accompanied by a cloud of dust that almost blinds Santiago- "The area was swirling in dust so intense that it hid the moon from view" (p. 104) and when "the blinding dust had settled a bit, the boy trembled at what he saw" (p. 104). While the alchemist and Santiago were on their way across the desert, they were imprisoned by a warring tribe who mistook them for spies and wanted to sentence them to death immediately. To buy some more time, the alchemist told the other tribesmen that Santiago was actually an 'alchemist' who understood the forces of nature and that if he wanted to, he could destroy their camp just with the force of the wind. The chief of the tribe gave him three days' time and told them that if on the third day, Santiago failed to turn himself into the wind then both of them would be killed. What is wind if not a mixture of dust and air?

With the help of the alchemist, he learns how to speak the 'language of the world' which eventually helps him communicate with the sun, the desert and the wind and thus conjure a literal storm made of dust and sand which threatens to blow away the camps- "it was worse than a storm at sea. Their horses cried out, and all their weapons were filled with sand... They could barely see the boy" (p. 141). When the storm 'simum' ceased to blow, everyone looked to the place where Santiago had been standing, but "he was no longer there; he was standing next to a sandcovered sentinel, on the far side of the camp" (p. 146).

We don't know for sure how an ordinary boy like Santiago managed to pull off this stunt but if we are to be sceptical, to take this performance with a grain of salt and conclude that it was all a staged performance- perhaps a part of the alchemist's plan who was well aware of an approaching sandstorm and thus deliberately asked for three days' time and then Santiago merely took advantage of the blinding sandstorm to travel to the opposite side of the camp without being seen, it is still the distracting power of 'staub' that has been used as a weapon to trick the enemies just like stage magicians and con artists resort to creating 'diversions' in order to execute their plans. Even if we are to take the text literally and believe that Santiago had actually turned himself into the wind, it is still 'staub' that enables the whole transformation, it is 'staub' that transports him to the other side of the camp and it is 'staub' that puts a veil over the eyes of the tribesmen while all of it plays out. Here is where 'staub' and 'zerstreuung' unite in true sense.

Santiago thereafter becomes a legend. He goes to the Egyptian pyramids and instead of finding a treasure there, he comes across another omen that takes him back to the abandoned church where we find him right at the beginning of the novel. Things come to full circle and Santiago finds a treasure chest right where he originally belonged even before he had dreamt of travelling. Now one might be tempted to pause here and question why. Why then did he follow the trail of distractions, travel to the Egyptian pyramids, get beaten up, robbed of all his life's saving, work in a crystal store for a year and waste so much time if his destiny was present right where he began, right back at home? That is simply because finding the treasure was not his only destiny. Learning the language of the world was his destiny, conjuring up the sandstorm was his destiny which he couldn't have possibly accomplished without the alchemist's help. Finding the one true love of his life, Fatima, a woman of the desert, was also his destiny. Helping the crystal merchant multiply his profits and flourish in his business was also his destiny. The dream of the Egyptian pyramids was something that united all of these destinies into one journey, one travel, something that the boy has dreamt of doing all his life.

\section{BRIDA}

\subsection{Distraction in Brida}

"I want to learn about magic," (p. 9) is the very first line with which Coelho's novel begins. When asked why Brida wanted to learn about magic, her answer was "so that I can learn about the occult powers, and possibly how to travel back into the past and forwards into the future" (p. 9) Theists would immediately label Brida's desire as a form of 'religious distraction' away from the path of God. Brida was a witch, an outcaste belonging to family of women who were burned at the stake for deviating from the path of light and choosing to follow the path of night instead. Her desires of time travelling and being able to wield supernatural powers would be labelled as 'derangement' or 'insanity' by rational, scientific minds.

In her first interview with the Magus, Brida was asked to place herself in a situation where she would suddenly find the love of her life one day and then the Magus asked her 
to answer with total honesty if she would choose to follow her love or continue to learn about magic. Love here was presented to Brida as a potential distraction that would lure her away from the path she wanted to follow. Brida hesitated a great deal before answering that she would give up everything for love, thus succumbing to the distraction. Contrary to her expectations, the Magus was extremely impressed with her answer and Brida learnt soon after that finding one's soulmate was the sole objective of anyone who wanted to learn about magic. So, love, rather than being a potential source of distraction was in fact the goal.

As though echoing the words of the king of Salem from The Alchemist, the Magus further tells Brida, "Disappointment, defeat and despair are the tools God uses to show us the way," (p. 17) all of these emotions being the consequences of succumbing to distraction. In reply, Brida says that these were "strange tools" and that they "often dissuade people from carrying on" (p. 18). During her first lesson, Brida is asked to spend a whole night in the forest alone. She, however, found it almost impossible to relax and images of scorpions and snakes that might be living underneath the rock on which she sat continued to distract her from focusing. She also found herself distracted thinking about the Magus, "Perhaps he found me interesting. Perhaps he even wanted to make love with me" (p. 20). She further found herself preoccupied with the thoughts of childhood ghosts and of the possibility that the Magus had perhaps signed a pact with the Devil and was offering her up as sacrifice. However, it is precisely her inability to relax that ultimately helped her learn the value of faith and taught her how to have courage, thus successfully completing the first lesson and advancing a step nearer towards her goal.

The importance of 'zerstreuung' in Brida reaches its crescendo when Brida sits before her tarot deck, hopeless, because she cannot find any meaning in the cards. A distracted individual as Brida, who has never persevered in anything she began but skipped from one interest to another, was about to give up on the Tradition of the Moon and disappear because she thought she wasn't cut out for it. So, she called up Wicca, her new teacher, deciding to take a leave, when Wicca started bombarding Brida with a stream of irrelevant information about caretakers, pensioners and how the plumber never came to fix her kitchen sink even though she had called him up several times. Wicca kept talking ceaselessly and Brida realized that she had never experienced anything so tedious before. "She kept trying to distract herself with the cards on the table," (p. 53) and that is when she started noticing little details on the cards that she had never noticed before. The tarot cards soon began to show her fantastic scenes and Brida felt like "her mind was miles away, travelling, wandering about in places she'd never been to before" (p. 53).

A triple distraction is at play here. Brida, distracted away from the Tradition of the Moon by her inability to decipher the language of the tarot, calls Wicca up to take a leave, who further distracts her by speaking at length on things that were of little importance to her, Brida further tries to distract herself from the tedium generated by Wicca's balderdash by looking at the cards before her and that is when, in the trance of this triple distraction, she unearths the sacred narrative of the tarot, something she had failed to do all this time no matter how hard she tried. "I know what happened," (p. 54) Wicca told Brida after she had snapped out of her trance, "It was a trick" (p. 55). Wicca has thus used distraction as a trick to make Brida finally be able to connect with her tarot deck. The creative, ludic emancipatory potential of distraction thus comes to the fore most prominently here.

On a similar vein, falling in love with the Magus and making love to him was a further distraction that Brida encountered towards the end of her journey while she was still in a relationship with Lorens, her boyfriend. But far from being a distraction that estranged her from Lorens or her greater purpose, falling in love with the Magus was a kind of distraction which was destined for Brida. The Magus was her soulmate, he knew it the moment he had set his eyes on Brida, and finding one's soulmate was one of most important objectives that anyone following the two traditions had to accomplish. Hence, here too, the distraction in love that Brida experienced was equated with her destiny and it helped her advance further towards her real purpose. There was series of things she had to accomplish before she could be initiated into the Tradition of the Moon at the Witches' Sabbath, finally come face to face with her destiny and start using her gifts for the greater good of the world.

\subsection{Dust in Brida}

Brida goes over to the realm of the earth, and by extension dirt and dust, when she decides to seek the guidance of the Magus who lived in the forest. It is in this realm that Brida learns most of the lessons of the Tradition of the Sun. It is in this forest that Brida spends a night alone sitting on a rock constantly haunted by the fear of being attacked by scorpions, snakes and ghosts and ultimately learns the value of faith. It is further in this realm of dirt and dust that Brida lays down directly on the earth with crystals on her forehead and on top of her navel and is able to travel back in time, unearthing the mysteries of her past life. She constantly has to be in direct contact with the dust in order to be able to achieve that state through which she can explore the secrets of her past lives. The dust, symbolized 
by the element of earth, helped Wicca to distract Brida away from her present reality and make connection with her past.

Having made connection with her past life, when Brida walked through the cathedral that would ultimately lead her to her soulmate from her previous life, she noticed that the church "pews were covered in dust" (p. 67). This is the first direct reference to dust that we find in the novel. She was also aware of the "unpleasant feeling of the dusty floor" (p. 67) beneath her bare feet. She stared at the "dusty tomes" (p. 68) and decided that she should go there more often and give everything a good clean just like Santiago did with the crystal glasses in The Alchemist. All the dust that Brida encountered while she walked into her past life merely meant that her past "was grubby and neglected" (p. 68) and she herself realizes that. Just like the crystal glasses in the merchant's store, her past life was gathering dust, owing to the fact that they were never engaged with. She can fulfil her destiny only once she revisits her past, cleans up the dust and learns about the past identity. Similarly until Santiago had cleaned the dust off the crystal glasses and attracted fresh customers into the store, a part of his destiny would have remained unfulfilled. Just like the films of dust on the crystal ware distracted potential customers away from them, Brida's obliviousness to her past is what allowed the dust to gather on her previous lives.

Brida further is a symbol of 'dust' herself. Her mind is like the dust that disperses at the slightest provocation. She jumps from one activity to another, never finishing what she once started. Once she faces an obstacle, she chooses to abandon that particular interest and move on to a new, different one. She first chooses the Tradition of the Sun, then she shifts to the Tradition of the Moon and when she cannot make sense of the tarot cards, she thinks of abandoning the Tradition of the Moon. Like the dust, she cannot settle down in one place for a long time. She's blown away by the wind of various distractions. Even in love, she finds herself unable to commit to anyone. Her head explodes with thoughts, she is continuously distracted, unable to relax, unable to focus on any particular thing or course of action. Just like dust, she is mostly all over the place. Her incessant mental agitation parallels Santiago's intense physical need for continuous mobility. In that way, Brida too becomes the symbol of the complex trinity of 'staub' (dust), streuung (dispersion) and zerstreuung (distraction).

\section{CONCLUSION}

The themes of dust (staub) and distraction (zerstreuung) have thus been used in The Alchemist and Brida in a unique way where distraction is seen less as a 'vice' and more as a 'virtue'. Even if those distractions may seem like mistakes at the outset, the protagonists, however, eventually realize that those mistakes are essentially good omens. Unlike La Bruyere's figure of Menalque, the picture of distraction, who keeps getting himself into trouble or situations of embarrassment due to his absentminded nature, Paulo Coelho's protagonists, Santiago and Brida, do not succumb to distractions, they triumph in them.

Here is where Coelho comes very close to the writings of Walter Benjamin whose view of distraction is a lot more complex than is presently found in educational philosophy. "Benjamin argues that cities are not only places of negative forms of distraction (as mere diversions), but also places for cultivating productive distraction in the form of an open and alert attunement to new ways of experiencing and perceiving the relationship between world and self" (Lewis, 2019). He refers to it as "the art of straying" (Benjamin, 1931-34). That is precisely what is happening in The Alchemist. From the very beginning Santiago is trying to perceive and experience the relationship between the world and his own self. That is what he calls 'the language of. the world'. He wants to learn the language of the world and the alchemist helps him to achieve that, and that is precisely how he ends up conjuring this dust storm, this sand storm towards the end of the novel which not only saves his life but also immortalizes him.

We can all agree on the fact that the. dominant discourse that surrounds the word 'distraction' is essentially not a very positive one. What the texts are trying to do is to offer a counter discourse and not essentially place distraction within any sort of binary, like positive or negative, good or bad, virtue or vice. It is trying to take it out of the cloud of negativity, and make us look at the other possibilities, the latent potential of distraction which is quite emancipating unlike what the conventional sense of the term suggests. Distraction doesn't jump from being a vice to a virtue based on the outcome. But rather distraction becomes a word that resists all sorts of binaries, because we cannot determine right at the outset where it's going to lead us or where we are going to end up after having followed the breadcrumb trail it leaves for us.

The words 'virtue' and 'vice', 'positive' and 'negative' used in this paper with. regard to distraction have not been used to place distraction within a binary but rather reiterate how society views distraction and goal achievement in general, as though they occupy two diametrically opposite ends of a spectrum and can never go hand in hand. And that is what the two novels seem to counter. In these two narratives, distraction doesn't occupy a space at either end 
of the spectrum but rather distraction becomes the spectrum itself.

This is how Coelho takes a different route to the same subject. What he explores in his works is the creative, ludic, emancipatory potential of distraction in which dust plays a very important role. Dust has repeatedly been used as a catalyst, facilitating positive distraction at the most important junctures in the two novels, thus enabling Paulo Coelho to contribute to the legacy of removing the stigma or the negative connotations associated with the word 'distraction' and giving it a new, constructive meaning.

\section{REFERENCES}

[1] Distraction. (2019). Wikipedia. Retrieved 18 February, 2021, from https://en.m.wikipedia.org/wiki/Distraction

[2] Distraction Noun. (c. 2021). Oxford Learner's Dictionaries. Oxford University Press. Retrieved. 18 February https://www.oxfordlearnersdictionaries.com/definition/engl ish/distraction

[3] Mahoney, K. (2019, 28th January). What Causes Spiritual Distraction? [Weblog]. Retrieved 18 February 2021, from https://www.learnreligions.com/what-causes-spiritualdistraction-712617

[4] Descartes, R. (1637). Discourse on Method. Netherlands.

[5] North, P. (2012). The Problem of Distraction. Stanford: Stanford University Press.

[6] Kafka, F., \& Brod, M. (2004). Blue Octavo Notebooks (Illustrated ed.). Exact Change.

[7] Coelho, P. (1933). The Alchemist. London: HarperCollins Publishers.

[8] Coelho, P. (2008). Brida. London: HarperCollins Publishers.

[9] Lewis, T. (2019). The Art of Straying: Benjamin on Distraction and the Informal Education of the City. Educational Theory, 69(2), 169-183.

[10] Benjamin, Walter. (2005). Selected. Writings: 1931-1934, 2(2) Cambridge, MA: Harvard University Press.

[11] Bruyère J, L. A. (2019). The Characters of Jean de La Bruyere, Translated by Henri Van Laun, United Kingdom: Good Press. 